\title{
6
}

\section{Sanctifying the Robe: Punitive Violence and the English Press, 1650-1700}

\author{
Philippe Rosenberg
}

It has become almost commonplace to treat punishment as a self-contained sociological phenomenon to be interpreted in terms of sentences or patterns of prosecution. Unfortunately, this widespread approach tends to overlook how punitive power itself has been understood. Much like its ancient and medieval predecessors, modern punishment is supported by a set of rituals, rationales and explanations that serve to legitimize it. This symbolic apparatus not only underwrites punishment, but also marks it off as something distinct from 'mere' violence. Rationales are therefore every bit as crucial to the sociology of punishment as are the severity of sanctions, the frequency of punitive action, or the legal machinery that surround its application.

The work of several scholars, including a number of contributors to this volume, shows that the practice of punishment in early modern English history was a complex and highly varied matter. It combined harsh physical violence in some cases, and the discipline of fines, shame and indentured service in others, with the exercise of mercy and restraint. Mandates issued by the state, and ideas voiced by the theorists who struggled with the foundations of the right to punish, came head to head with local realities in the administration of justice. Contrary to appearance, however, a number of common threads linked these various elements. Punishment usually rested on a measure of popular consent: its deterrent message was addressed to popular audiences, and the authority to punish stemmed from juries and magistrates acting jointly in the name of the sovereign. With this in mind, we should seek to better grasp the views about punishment that were elaborated either by or for the national and local élites, and, better still, for the middling ranks of commoners who supplied accusations, entered evidence, served as jurymen or collaborated in the machinery of deterrence. What were the arguments that led these individuals to accept the courts' authority to inflict 
violence or other hardships as a matter of course? How did they decide that the violence carried out by the state, though sometimes quite brutal in its methods, was different from the violence carried out by the criminals? In what ways did they distinguish between proper and improper modes of administering retributive violence, long after any honour-derived rationales supporting direct retribution or 'composition' had ceased to persuade?

These questions all centre on the representation and ideology of punishment, a topic that has attracted some attention from historians. The two most entrenched arguments concerning the ideological dimensions of early modern punishment focus almost exclusively on the legitimization of state power and overlook questions about the legitimacy of violence itself. Followers of Michel Foucault claim that, before the rise of prisons and the internalization of discipline, punishment was an occasion for the state to advertise its power. Criminals were disturbers of the king's peace and the state's rituals of retribution provided a means for restoring lawful order as well as the integrity of royal power. The state effectively transformed the dismantled body of the criminal into a badge of its authority over its subjects. ${ }^{1}$ A second prominent argument, congruent with the first, maintains that punishment was as much an occasion for social, political and spiritual contrition as it was a means of deterrence. Punishment was an occasion for asserting or reasserting the merits of obedience and submission to existing authority. In the view of J.A. Sharpe, the criminal's formulaic words of repentance supplied the necessary admission that the state was right to exact retribution. Faced with earthly punishment, the sinner turned to God for forgiveness in a process fundamentally akin to the experience of conversion. The pamphlets and broadsheets that summarized the criminal's life, confession and dying speeches showed where the sinner had strayed, but also offered reassurance that he or she had finally rejoined the fold of the political and religious community. The ordeal of punishment sent a warning to other potential criminals, but also served as a lastditch instrument of salvation for the condemned. ${ }^{2}$

These arguments have opened up to discussion the ideology of punishment, but their limitations are beginning to show. The display of state power is an altogether obvious feature of the spectacle of corporal punishment, yet the argument which Foucault and his successors have put forward never truly gets beyond this issue of display. Unless one mistakenly assumes that subjects somehow lived in perpetual awe of their rulers, or that they mindlessly approved of the lessons of might, the argument fails almost entirely to account for the fact that the public supported the state's right to punish. More seriously still, it overlooks the considerable extent to which propagandists tried to dissimulate the state's power. In early modern England, as we shall see, pamphleteers routinely claimed that the violence witnessed in punishment was not the state's at all, but that of God.

Sharpe's contribution continues to hold a great deal more water than Foucault's, yet it overlooks a few important elements in the early modern 
ideology of punishment. Printing the criminal's acts of repentance certainly linked punishment with the wider narrative of human sin and divine judgment that held sway during this time. But if the whole point of these verbal performances was to commemorate submission and ultimate salvation, why, then, were dying speeches routinely accompanied by formulaic recitations of the criminal's cruelty or depravity? As we shall see, in seventeenth-century writings, the public vilification of the criminal remained as significant as the criminal's admission of guilt. It sustained what was, in effect, an attempt to expunge ambiguity: crime was crime, and therefore considered a form of violence; punishment was something else entirely.

While careful consideration of dying speeches and assize sermons, sheds light on retributive justice and its ideological moorings, these materials are more illuminating when considered in combination with other types of public commentary. The sketch that follows focuses mainly on print, especially the pamphlet press, leaving aside opinions conveyed through other channels of expression such as everyday speech and legal documents. It puts the emphasis on the supply of arguments, while dealing with their consumption and internalization in a more cursory manner. The quarry here, then, lies in the varied set of rationalizations which the shapers of opinion offered in order to justify punishment, including the effect of these rationalizations in fostering positive, as well as negative, evaluations of magisterial power. The focus is on the seventeenth century, with a special emphasis on its relatively neglected second half. This period, it bears noting, has received less attention than the late sixteenth and early seventeenth centuries, when the brutality of English law was at its peak, or than the eighteenth century, when an expanding 'Bloody Code' made a host of new property offences punishable by death, transportation, or imprisonment. ${ }^{3}$

Three concurrent trends affected the treatment of retribution during the late seventeenth century. The first involves a simple, quantitative proliferation of printed materials addressing punishment and similar categories of justified violence. The second and perhaps more surprising trend was one towards an increasing sacralization of punishment, the effect of which was to minimize its apparent violence. Sacralization, as we will see, represented a complex ideological pattern, keyed in part to a providentialist understanding of violence. The third trend was directly connected to the second; it involved an increasingly sharp dichotomy, opposing the benevolence of punitive authority to the cruelty of those who were subjected to it. Like so many dichotomies, this one was double-edged. It was used to justify the suppression of 'inhumane' elements in society, but could just as easily be turned against magistrates accused of judicial cruelty. As we shall see, the ideological fluidity that characterizes seventeenth-century discussions about retribution may well have stemmed from the fact that people were uncertain about whether the judges themselves were criminal or just, violent or benevolent. 
II

The seventeenth century was a period of massive expansion in the volume and topical range of printed matter. The remarkable thing, however, is that the relative importance of punishment and retribution within this expanding field of print was more than keeping pace with the overall growth in output. Indeed, the proportion of these particular topics with respect to the whole did not decline until the eighteenth century, and then only gradually so. This finding is all the more surprising in that printers and booksellers had begun publishing on a vast array of new subjects that spanned everything from chemistry to the art of the flute.

Though imperfect, The Short Title Catalogue (STC) provides one of only a few usable sources for evaluating the production of print. Its chief and most obvious limitation lies in the fact that it only lists the titles of surviving materials, leaving out many works that are no longer extant. It also fails to provide any record of the numbers of copies produced or sold. It is problematic, furthermore, in that cataloguers entered different editions, reprints and sometimes copies of the same works, as separate records. A certain number of titles, therefore, appear more than once in the list. With these limitations in mind, by dividing the production of print into discrete 25 -year periods, we find that between 1550 and 1749 , words such as 'justice', 'revenge' and 'punishment' made up a steady 0.8 to 2.7 per cent of total production ${ }^{4}$ (Table 6.1). These were significant figures that compared favourably with those obtaining for other important topics of the day. In 1650-74, the word 'government' accounted for 2.2 per cent of titles; in $1675-99$, it was 2.1 per cent. In the same range of years, 'Jesus' accounted for between 1.5 and 2.8 per cent of titles. The words 'popish', 'popery' and 'papist' which evoked the great bugbear of the late seventeenth century, the Catholic threat, appeared in some 1.0 to 2.5 per cent of the period's titles. Counting the appearance of certain keywords is, of

Table 6.1 Titles containing specified keywords per each 25-year period

\begin{tabular}{lllllll}
\hline Years & \multicolumn{5}{c}{ Range of occurrence (\%, no.) of: } & \multirow{2}{*}{ Total } \\
\cline { 2 - 6 } & $\begin{array}{c}\text { 'execut } \\
\text { (ion/ed)' }\end{array}$ & 'justice' & 'punishment' & $\begin{array}{c}\text { 'revenge') } \\
\text { 'vengeance' }\end{array}$ & 'hang (ed/ing)' & \\
\hline $1550-74$ & $0.13 \%(5)$ & $0.15 \%(6)$ & $0.28 \%(11)$ & $0.15 \%(6)$ & $0.13 \%(5)$ & $0.84 \%(33)$ \\
$1574-99$ & $1.10(74)$ & $0.10(7)$ & $0.60(40)$ & $0.10(7)$ & $0.06(4)$ & $1.96(132)$ \\
$1600-24$ & $0.80(93)$ & $0.07(8)$ & $0.32(37)$ & $0.17(20)$ & $0.13(15)$ & $1.49(173)$ \\
$1625-49$ & $0.51(145)$ & $0.65(184)$ & $0.58(164)$ & $0.15(42)$ & $0.25(71)$ & $2.14(606)$ \\
$1650-74$ & $0.75(235)$ & $1.04(325)$ & $0.34(105)$ & $0.17(52)$ & $0.26(80)$ & $2.56(797)$ \\
$1675-99$ & $1.36(624)$ & $0.67(307)$ & $0.26(120)$ & $0.14(66)$ & $0.29(134)$ & $2.72(1251)$ \\
$1700-24$ & $0.76(433)$ & $0.47(264)$ & $0.24(136)$ & $0.08(43)$ & $0.12(67)$ & $1.67(943)$ \\
$1725-49$ & $0.58(317)$ & $0.37(200)$ & $0.26(140)$ & $0.07(39)$ & $0.06(32)$ & $1.34(728)$ \\
\hline
\end{tabular}

Source: RLG's Eureka, ESTC (English Short Title Catalogue): http://eureka.rlg.org; June 2002. 
course, an imprecise yardstick. A given word will recur, or several different keywords coincide, within a single title. The choice of words itself is always somewhat arbitrary. Rubrics like 'execution', 'justice', 'punishment', 'revenge' and 'hanging' (including related adjectives and verbs) only stand out because they recurred frequently. Meanwhile, words such as 'condemned' and 'condemnation' occur too often in discussions having nothing to do with punishment to be of any use; in early modern titles, to take a banal example, one 'executes' orders less often than one 'condemns' opinions.

Although these figures constitute only a rough guide to the diffusion of materials on punishment, they tell a revealing story. The preponderance of references to execution within the overall distribution of titles is this survey's most obvious result. Over the course of the period examined, 'execution' was a more prevalent term than 'punishment'. Many of the titles that discussed 'executions' conformed to the pattern described by J.A. Sharpe; they publicized the capture, trial, conviction and dying behaviour of various felons, most of them traitors and murderers. But while considerable, the amount of attention bestowed on executions varied over time. In the 75 years from 1600 to 1674 , the proportion of titles that referred to executions declined slightly relative to what it had been in the closing decades of the sixteenth century, the volume of titles that referred to 'justice' expanded to fill the gap. The proportion of titles that directly invoked 'punishment', 'hangings' and notions of vengeance, fluctuated only moderately throughout the entire seventeenth century. We should note, too, that the appearance of terms connected with vengeance underwent a very progressive decline as of 1675. Allusions to punishment had begun to fall a little earlier, after reaching a high point of just over half a per cent of surviving titles in 1625-49.

On the whole, punishment held its own - this, in spite of the fact that it might easily have been overshadowed by a flood of new interests and new printed materials. But given the rapidly expanding pace of publication, even the most stable percentages would have translated into a dramatic expansion in the exposure of English-speaking subjects to materials on justice, executions and punishment. A brief review of the totals expressed in absolute numbers bears this out more clearly. The 25-year totals increase from 33 titles in $1550-74$ to 173 titles in 1600-24, and then to a staggering 1251 titles by the closing decades of the seventeenth century. The public's familiarity with the sorts of materials surveyed here would have depended, ultimately, on such factors as the number of copies printed and sold, the network of geographical distribution, and the more intangible exposure of illiterate or partially literate audiences to these texts through reading aloud. Although diaries hold some clues that these materials were read and publicly discussed, we have little further evidence of the diffusion and reception of these texts. ${ }^{5}$ What we can say is that they were produced and published on such a scale as to suggest that the supply must have corresponded to a substantial demand. We also should keep in mind that the numbers given 
here are, if anything, much too low. Many titles, especially those of short, cheaply-produced leaflets, simply did not survive to be entered into the STC. Not only this, but countless more books and pamphlets discussed punishment, retribution and their rationales even though their titles never directly alluded to this fact. Works on topics as diverse as military campaigns, the upbringing of children and apprentices, or the materiality of hellfire, often included theories or discussion about the appropriateness of punishment. Printed newsbooks, though not primarily concerned with reporting on punishment, also commented on executions, punitive measures, martial law and other instances of retaliatory violence. The exact numbers, however, would still say next to nothing about the rationales that authors offered to justify punishment, and this makes it preferable to move to actual contents.

\section{III}

Criminal biography, which accounts for a good proportion of the printed materials surveyed above, has been noted for its combination of sensationalism and fatalism. It typically presents punishment as a natural consequence of crime, just as crime itself was considered an outgrowth of sin. Alexandra Walsham and Malcom Gaskill have commented that crime narratives often portrayed criminals undone by the miraculous discovery of their deeds, as when corpses suddenly began to bleed in the presence of the murderer, or when mute children regained their voices just in time to identify their parents' killers. The agent in these stylized tales of retribution was an all-seeing God who invariably found some way of exposing criminals. Gaskill maintains that providential narratives were reassuring in a period in which the machinery of policing and the methods of prosecution remained rudimentary and therefore unreliable. He also claims that, by the latter half of the seventeenth century, these kinds of stories were on their way out, partly because the reliability of investigations improved and therefore lessened people's psychological reliance on the expectation of divine justice as a corrective. ${ }^{6}$

In fact, many authors in the late 1600s persisted in seeking providential underpinnings to explain the criminal's violent fate. Older tales recounting providential downfalls, like John Reynolds' collection in The Triumphs of God's Revenge (first published in 1635) continued to be reprinted and sold as before. Meanwhile, contemporary authors simply adopted more subtle forms of providential thinking, in which the intervention of a miracle gives way to a more diffuse sense of divine agency in bringing about the criminal's downfall. This shift may have been due to tamer stylistic norms, and not to any alteration in the authors' or the public's expectations concerning the efficacy of the judicial system. Be that as it may, these various forms of expression converged in purpose and effect: they worked to deflect attention away from the violence of executions. In so doing, they contributed to the greater legitimacy of capital convictions. 
One of the claims common in accounts of crime and punishment in the latter half of the seventeenth century was that felons were self-victimizers. A ballad published in 1675 offers an excellent example of this link between self-victimization and punishment. It tells the story of Henry Symball and William Jones, sentenced to die in Fleet Street, London, for the murder of Sir Richard Sandford. ${ }^{7}$ In describing their demise, the balladeer reminded readers that the punishment of hanging would deter other potentially violent individuals from committing murder, but he also framed his discussion of exemplary justice in terms that emphasized the murderers' selfdefeating fury. In this balladeers' view, Symball and Jones were sentenced to die as a 'reward for impiety'. Death by strangulation was 'their due'. Following this reasoning, the murderers could never have hoped to escape detection and eventual punishment. Thus, their thoughtless actions ended up causing not one, but rather three pointless deaths. The law, in this case, was only a means of redress. ${ }^{8}$ In evoking 'dues' and 'rewards', the author drew attention to the deadly wages of sin; to the fact that the criminals' deaths were foreordained as part of an economy of retribution independent of the actual workings of the law. The two men had earned the fate that awaited them.

Some authors were more sparing in their descriptions of punishments. The anonymous author of The Cruel Murtherer, Or the Treacherous Neighbour (1673) provides an example of a certain curtness in the description of punishment. Although he lavished great attention on every detail of the murder of Alice Stephens and her young daughter in the parish of Stocksay, Shropshire, when it came time to describe the murderer's fate, the author switched to a more muted style of rhetoric:

On Tuesday last, the 11th of March, [Thomas Reignolds] received his trial; he pleaded guilty and on the Thursday following the sentence was passed upon him; he was adjudged to be hanged in chains on Aldon's Mind, near the place where he did the murder. Accordingly, on Thursday March the 20th he was executed. ${ }^{9}$

The violence that the criminal had committed required a lengthy explanation, but the violent destruction of the criminal did not. There is no sign of providentialism here. This author's assumption, to the extent we can that detect it through his silences, seems to be that violent punishment was simply normal. The gruesome addition of leaving the corpse to rot on the gibbet somehow befitted the crime. On the title page, however, the reader was confronted with another interpretation of punishment, in the form of biblical citation: 'The wicked', he or she learned, 'is snared in the work of his own hands'. Whether this was the author's inclusion, or merely the publisher's matter-of-fact pronouncement on punishment, it reinforced the idea that the criminal had victimized himself. 
This kind of emphasis was found in many pamphlets and songs, as well as in tales belonging to more elaborate literary genres. The literature of wonders stands out in this respect. John Reynolds' previously mentioned Triumphs of God's Revenge offers one of the finest examples of the wonder genre. His best-selling set of stories was initially produced in installments between 1621 and 1625 , but in 1635 they were bound in a single volume and the compilation was subsequently reprinted in various editions well into the eighteenth century. ${ }^{10}$

Reynold's tales presented the reader with a stereotypical portrait of the murderer swept away by his or her own violence. One of these tales, for example, begins with the return from service in the Adriatic of de Salez, who finds his father pressing him to marry a colleagues' crippled daughter. Salez, we learn however, is already in love with a notoriously loose woman by the name of Mademoiselle de la Hay. His descent into violence begins when a rival challenges him to a duel and loses. Meanwhile, la Hay eliminates her own rival (the cripple), with the help of a poisoner. With the rivals out of the picture, Salez rides off to Paris to ask for his father's blessing to marry, but when the latter refuses, Salez stifles him in the middle of the night. After a brief mourning period Salez braves public scandal and marries la Hay, but after only three months, she offers her favours to another man. At last, Salez repents the murder of his father, but as he begins to talk of divorce, la Hay's fear of destitution leads her to slit his throat. Everything unravels from here. As de Salez lies dying, his servants hear him accuse his wife. The lieutenant criminel arrives on the scene, and de Salez confesses his own parricide before he finally expires. Shortly thereafter, la Hay is seized in a church and racked until she admits to having murdered her husband. Finally, the judges condemn Salez' dead body to public desecration, and sentence la Hay to public burning after prior strangulation. But, as she confesses, la Hay unwittingly reveals her guilt in the death of Mademoiselle de la Frange, and the judges proceed to stiffen the penalties against her, ordering that she be burnt alive rather than dead. Even the poisoner ends up being caught and broken on the wheel. ${ }^{11}$

Although this story was likely meant to titillate, the author felt a need to rationalize these criminals' violent ends, something he accomplished by inserting punishment into a tragic progression of violent acts. In the story, Salez and la Hay, unable to restrain their passions, set in motion a train of events to which they inevitably succumb; from victimizers, they become self-made victims. Reynolds' running commentary on the events in this sorry tale confirms the case for unavoidable consequences. At one point, for instance, he inveighs against la Hay, as if to warn her: 'if thou proceed and finish this infernal and bloody stratagem of thine, although thou chance to go unpunished of men, yet the Lord (in his due time) will find thee out and both severely scourge and sharply revenge and chastize thee.' Similar words of warning threaten both the poisoner ('beware for the sword and arrow of 
God's just revenge and revenging justice threatens ye with no less than utter confusion and destruction') and de Salez ('we shall shortly see this mask of his devilish hypocrisy pulled off and this inhumane parricide both shamefully and sharply revenged by the just judgement and finger of God'). ${ }^{12}$ When the judges perform their function by condemning all three murderers to death and degradation, Reynolds intervenes once again and denies them agency, turning to divine Providence to provide his ultimate justification. But while it was 'God's revenge' that triumphed over murder, God was not interested in taking lives. The criminals themselves triggered the process. Punishment qualified as the 'bitter fruit' of their own actions. ${ }^{13}$

Although these various allusions might be viewed as simple devices meant to drive the action of a sensational tale of deceit and murder, they coincide nicely with the didactic purposes of Reynolds'stories. For Reynolds, stories offered fresh and vivid reminders of Biblical lessons - reminders that left 'a better imprint on the mind' than the Bible itself. One of the lessons he selfconsciously sought to impart was that divine justice implied perfect redress: the redirection of violence towards its point of origin. As he explained in his preface, the human tragedies which murder provoked proved the truth of David's words: 'whosoever maketh a pit for others shall fall into it himself; for his mischief will return upon his own head and his cruelty fall upon his own pate. ${ }^{\prime 4}$ God's customary recourse was to let the effects of violence run their course, so that the instigators found themselves caught at their own game.

For Reynolds, the idea that violence would boomerang against the perpetrators of violence was intricately tied to the notion of divine justice. The same idea, however, circulated without necessarily being tied to providential explanations. An abridged, pirated version of Reynolds' very own stories, published by a certain T.M. in 1661, illustrates this well. The dominant themes in T.M.'s version of Reynolds' tales include disobedience, honour and the proper uses of punishment - themes which correspond to the author's own preoccupations with the Regicide and the 'judicial murder' of Royalists following the Civil Wars. ${ }^{15}$ For T.M., punishment stemmed from murder, and murder stemmed from disobedience without further ado. Providence played only a cursory role in this trajectory.

Yet the author still made a careful point of talking about the many 'miseries' that caught up with the criminal as part of the cycle of violence. The title of his compilation itself bears the stamp of a residual concern with divine retribution in that it links murder and vengeance ('Murthers Revenged') to a biblical injunction customarily associated with lex talionis ('Blood for Blood'). There is, in other words, ambivalence here. In T.M's hands, the story of de Salez and la Hay is turned into a straight narrative with only the shallowest of didactic pretensions; the purpose of the story is to provide 'a lesson for all people not only to detest these foul sins in themselves but [to] abhor and hate them in all others'. On the other hand, the calamities that befall 
the three villains are still very obviously the logical culmination of their own violence. ${ }^{16}$

The points raised by Reynolds and T.M. apply to murder pamphlets and ballads in general, as well as to writings dealing with treason and rebellion. Similar points also obtain in materials treating less serious offenses, such as robbery, breaking and entering, and other property crimes. ${ }^{17}$ What differentiated all of these various works was not their subject matter - murder as against treason or theft - but rather, the greater or lesser extent to which the authors relied on providential arguments in order to justify the punishments meted out to the guilty. The providential treatment of retributive justice worked, in effect, to write the violence out of punishment. Punishment, according to the providentialist perspective, pertained to God not to human beings. The violence of punishment was nothing more than the justly redirected violence of the criminal. God, the source of all judgement, stood as the author of this redirection, but was not usually described as violent in his own right. Judges and jurymen, for their part, were almost invariably treated as the mere instruments or conduits in the supernatural accomplishment of 'justice'. Against this transcendent view of justice, less providentiallyminded authors presented a complementary idea, that of immanent justice. In this view, violence bred violence and 'the wicked' were 'snared in the work of their own hands'. These authors did not seek to substitute God's agency for that of men and women, but they usually paved over the actual violence of punishment by making a point of describing it as a direct 'reward', 'wage' or 'product' of the criminal's misbehaviour, rather than as a new and separate instance of aggression.

Putting aside differences in emphasis, both of these interpretations shared a good many traits in common. Following both views, punitive violence was the outcome of an unstoppable sequence of events that began and ended with the criminal. Justice, whether it was imagined to be transcendent or immanent, was portrayed as a process independent, in important respects, from the agency of the courts or the state. The propensity of commentators to describe punishment in these terms forces us to call into question the standard Foucauldian case: early modern executions, it seems, were not supposed to be interpreted as conscious and deliberate displays of state authority. Far from drawing attention to the state's triumph over the criminal, authors and pamphleteers insisted that violence originated from the criminal's own actions; in their accounts the state is a participant, but an inessential one - the simple instrument of a natural ordering of things.

A common pattern of sacralization appears, in effect, to inform these two somewhat divergent approaches to the abstraction of punitive violence. This is the juncture at which Foucault's history of punishment fails as an analytical guide and René Girard's model of the relation between violence and 'the sacred' emerges as a more appropriate one. Girard's claims have centred on the role sacrifice plays in archaic cultures. In his view, the ritualized killing 
of preselected scapegoats in ancient societies served to restore peace to communities threatened by cycles of revenge killing. The scapegoat, according to Girard, was typically an innocent, selected either at random or according to ritualized prescriptions. In slaying this innocent sacrificial victim, the community confronted the spectacle of its own violence. It simultaneously distanced itself from and, to some extent, rid itself of this violence. Following archaic modes of religious explanation, the sacrificial victim was 'taken' by a god whose power was identified with the community's own violence (roughly to the point of being conflated with it), but who was nevertheless considered separate and more powerful than the community. The spheres of sacrificial violence and of the sacred were therefore essentially one and the same; angry divinities transcribed the violent dealings of human beings. ${ }^{18}$

In formulating this admittedly schematic account of the sacrificial process, Girard notes that modern societies, governed by law, have shortcircuited the logic of sacrifice. In modern societies, legal institutions mediate between individuals and the threat of cyclical violence. These institutions either intervene, or are called upon to intervene, whenever a dangerously conflictual situation arises. Their role is to identify a guilty party, condemn or sanction that party, and thereby help people avoid taking recourse in private vengeance. But while Girard would not readily accept that this type of modern legal machinery ever produces or involves 'sacredness', there remains reason to suspect that, in the course of their historical development, legal institutions did, in fact, invoke 'the sacred' in order to foster legitimacy. Although we should reject a crudely evolutionary account of the transition from 'archaic' modalities of sacredness to modern, secularized modalities of law, early modern accounts of punishment still smacked of the 'in-between.' Several pieces that we have been examining, in particular those that were most overtly providentialist in their outlook, impute the violence of punishment to God. Virtually all the rest of these materials pave over the actual role of the law's agents or institutions in their descriptions of punitive violence. And the majority of them portray the liquidation of a given individual (or individuals) as the final act bringing cycles of strife, homicide and possible revenge to an end. In these various respects, early-modern arguments duplicate the process of sacralization described by Girard, including: (1) the tendency to read violence as something transcendent; (2) the denial of active violence on the part of the community; and (3) the closure which this 'final act of violence' is meant to provide to a community previously destabilized by violence.

The one principal disagreement between Girard and the early modern commentators has to do with the identity of the 'sacrificial victim.' In the legally-minded framework of seventeenth-century polemics, 'scapegoating' was irrelevant and deterrence far more to the point. The seventeenth-century 'victim' was a criminal, not an innocent made to bear the community's 
guilt. He or she had to be truly, not only metaphorically guilty and, in many cases, not only guilty but also unrepentant. ${ }^{19}$ The legal machinery, when it functioned properly, was there to ensure that this stipulation (the determination of guilt) was met before punishment was carried out. The criminal's guilt, in the eyes of both God and man, was the absolute precondition of a logic that made 'punishment' synonymous with 'justice'. The insistence on guilt in early-modern English culture thus clashes with the arbitrary selection of victims so vital to Girard's case. Girard's sacrificial victims were only retrospectively made to appear 'guilty' in the eyes of the sacrificial community. The victims of English justice, by contrast, were supposed to be guilty tout court.

John Seller's picture book on The Punishments of the Common Laws of England (c. 1678) supports this case for sacralization quite nicely. ${ }^{20}$ Seller's bookplates described the various forms of punishment in ascending order of severity. The illustrator ignored the fairly common punishment of fining, beginning instead with the drunkard's punishment of the stocks. From this point forward, we move through a list of increasingly serious sentences; from the 'cage' for the unruly, to the house of correction, whipping at the carts' tail, hangings, burnings and the punishments reserved for traitors. In all of these plates, save one (the house of correction), a crowd of onlookers beholds the violence taking place. Most of these spectators are quiet, but a certain number of figures gesture towards the criminal, perhaps as a way of marking the exemplarity of punishment. Whether the gaze is public or institutional, however, it virtually always signals the public's acquiescence in the punishment. The community is an explicit participant in the process of punishment. By contrast, the justices and juries responsible for handing out sentences are nowhere to be seen in these plates. The constable who oversees 'the punishment of the whipping post for vagrants and sturdy beggars', the beadle who carries out the whipping, and the mounted guards who keep order are the only reminders of the role of public authority in the infliction of sentences. The tendency towards sacralization, in Girard's sense of the term, is fairly clear here. The sacrificial crowd is present to stare down the guilty, but at the same time it distances itself from the violence taking place under its very nose.

On its own, a few tales on punishment and a single picture book cannot be treated as conclusive evidence that early modern authors sought to sacralize, rather than celebrate, the violence of judicial authority. But much of what is already known about the religious component of punishment, from existing historiography, dovetails with the framework of analysis suggested here. Sharpe's main point, namely that the convict's dying words provided an opportunity for the affirmation of authority and for the sinner's reconciliation with God, makes all the more sense if one considers that the people who recorded, edited and published these speeches also had a keen interest in sacralizing retributive justice. Any confessions or admissions on the part 
of the criminal that contributed to the commentators' efforts to transform a scene of violent punishment into a scene of contrition in the face of divine judgment would indeed have been ideal fare for appropriation.

In general, the sacralization of punishment fits in nicely with basic tenets in early modern religion. There was a strong overlap between the justifications for human punishment on the one hand and prevailing views of divine justice on the other. Homilists liked to remind their readers of the continuum between the spectacle of the gallows and the threat of hellfire. Until a changing theology in the eighteenth century began to cast doubt on the earlier image of hell as a place of endless torment, and until assumptions about the purposes of punishment began to change in its latter half, the organizing framework for interpreting punishment centred chiefly on the figure of a just, vindictive God at the head of a just and orderly state. ${ }^{21}$ The image of human punishment and that of divine punishment were, in fact, mutually reinforcing. Sacrificing the guilty helped to preserve the community by discouraging further violence. Since it was thought that deterrence created peace, punishment could easily be regarded as an enactment of God's desire for order on earth. Thus the assumptions made about divine judgment itself were connected to the logic of contemporary punitive practice. ${ }^{22}$

Yet religion, as always, was not all-encompassing. The ideological impetus to sacralize punishment, to sanitize it as well as turn it into abstraction, was consistent with more mundane realities reflected in such things as the geographical positioning of the gallows. In certain cases, convicted felons might be executed in some central space associated with their crime, but the gallows were deliberately erected in the liminal spaces outside cities and towns. ${ }^{23}$ Although this exercise no doubt owed something to a concern with public hygiene and crowd control, it also suggested an attempt to symbolically rid the city of its moral 'pollution'. The criminal was not only removed from the human community through execution, but also physically exiled to the outer margins of public space, just as the violence inherent in capital punishment was removed to a no-man's land. ${ }^{24}$

But if liminality was meant to convey sacrality, the well-known unruliness of crowds gathering for a public hanging would certainly have detracted from the purported solemnness of the event. ${ }^{25}$ Ordinary spectators were bringing their own expectations to executions and these expectations were not fully consistent with the tendency towards sacralization one finds in the printed pamphlets. Spectators made their own comments about the criminal's fate and their emotional responses varied from one execution to the next (they could be sad, somber, silent, angry or enthralled, depending on the case). One popular concern does, however, suggest that spectators subscribed in some part to the broad logic underlying sacralization: they expected complete proficiency from the hangman. The delivery of punishments had to be both appropriate and swift enough to spare the convict any unprescribed suffering. In cases where the gravity of the convict's crime 
mandated contrition, many spectators apparently expected it as a matter of course, as part of the requirements for 'making a good end'. ${ }^{26}$

The responses of spectators at executions take us beyond the pale of the literate world discussed above into a sphere of unwritten ideology that holds its own important implications for the normalization of punishment. As Susan Amussen has recently explained, in early modern communities 'discipline was the justification for punishment, and punishment was central to many other forms of violence'. ${ }^{27}$ Outbursts of violence were keyed to the administration of discipline in the home and the local community. ${ }^{28}$ To those involved in brawls or domestic disputes, what we would take to be violence did not necessarily register as 'violent' at all; almost any form of violence could be legitimated insofar as it was used to redress a wrong or discipline the unruly. These categories were unstable of course, and some people might well expose what some considered to be 'discipline' (wife-beating, for instance) for the violence that it really was, giving rise to a game of mutual accusations. Yet many men and women were clear on their categories and probably tended to view the machinery of legal prosecution as an extension of their own aspirations to discipline those who gave offence.

\section{IV}

Following the logic of sacralization described above, the exoneration of judicial authority from the infliction of violence required, as a counterpart, that spectators be absolutely convinced of the criminal's guilt. We should therefore expect to find that, aside from obscuring the violence of the criminal's end, authors would also use rhetorical mechanisms for underscoring and intensifying the criminal's guilt. Appealing to Gods' all-knowing gaze was one such device. God never erred: those who stood guilty before Him must therefore be at fault. References to witnesses, depositions and the court's judicious scrutiny of evidence constituted another register to much the same end: proving that the condemned must be guilty because reasonable people had found that it was so. Another mechanism, however, and one that played a preponderant role in the vast majority of tales and reports was simple vilification. Recent scholarship has tended to place strong emphasis on the theme of redemption. Historians and critics have shown, again and again, that early modern authors were bent on the criminal's atonement and salvation, something which depended, in part, upon being able to show that the criminal's condition was similar to that of other sinners. ${ }^{29}$ By shining their light on the redemptive element in criminal biography, these critics and historians have unwittingly left an equally important component of these tales out of the account: the part of the story in which the criminal is shown to be unlike most sinners and unlike most human beings. The condemnation of criminals in the press mobilized a convention-laden, highly stylized practice of name-calling. Much like older traditions of blame, this rhetorical 
practice relied on set formulas, the point of which was to sharpen perceptions of the criminal's guilt. Authors claimed repeatedly that criminals were inhumane, bloodthirsty, barbaric and cruel in the case of murderers - or sinful and hardened in the case of thieves. This was another way of saying that criminals, as a type of people, were depraved and not merely guilty in a legal sense.

The deep tension between the redemptive and accusatory strains in criminal biographies is especially clear in the story of Mary Cook, who killed her infant daughter in 1670 and instantly became the subject of two separate pamphlets. ${ }^{30}$ Cook exemplified the case of a woman beleaguered by her relatives and her own severe bouts of depression; 'melancholy' was how contemporaries described her condition. The authors who wrote about her were visibly divided between sympathy and an urge to demonize her as the embodiment of the stereotypically 'unnatural' mother. Their aspersions therefore have something of a hollow ring; they read like a recitation of pieties one finds hard to believe but cannot refrain from mouthing anyway. Yet the pieties in this case worked to a specific effect. They simultaneously assigned guilt and vilified the guilty. According to one author, Mary Cook was a 'cruel mother'. Her heart was 'obdurate and impenetrable', or else simply 'wicked'. She was the author of an 'unnatural, inhumane, notorious, material bowelless cutthroat murder'. ${ }^{31}$ Partridge and Sharp, the authors of a second pamphlet, referred pointedly to Cook's 'horrid murder', the 'ghastly' way in which she cut her child's throat ('laying aside all motherly bowels'), as well as the 'barbarous' tenor of her actions. ${ }^{32}$

One might assume that the outrage expressed through these labels was entirely related to the fact that the murderer was a mother and the victim her own child. The allusion to 'motherly bowels' certainly owed something to ideas about gender, which assumed that women - and especially mothers were supposed to exhibit a 'natural' sense of pity toward the young. In virtually every other respect, however, the authors' formulas drew upon a rhetoric that carried well-beyond the representation of 'unnatural motherhood' per se. The kind of language that was here directed against infanticidal mothers was also invoked with uncanny frequency throughout the seventeenth century to describe all manner of enemies and outcasts, be they papists, regicides, persecutors, cannibals, tyrants, pirates or plain murderers. The language in question also served to identify and castigate abuses of power and virtually every category of illegitimate violence. ${ }^{33}$ The specific ways in which different authors deployed the formulas that made up the language of illegitimate violence and criminal responsibility varied. Authorial inclinations, the criminal's identity, and the context of crimes and atrocities all had some bearing on the themes and labels that were selected. In the case of Mary Cook, the organizing principle lay in the theme of 'bloodshed'. The readers of both pamphlets were exposed to a barrage of allusions to the shedding of blood: Mary Cook's hands were 'colored by blood;' her knife was 'bloody;' her crime was likewise 'bloody' ${ }^{34}$ 
This choice of imagery can be imputed to sensationalism as well as to the urge to make a strong impression, since blood is a potent reminder of victimization. The graphically physical image of spilling the body's vital fluid (blood) concretizes an otherwise abstract offence (murder). The broader importance of the image of blood, however, was based on a biblical formula which the authors invoked repeatedly. As Partridge and Sharp observed: 'No sin committed against the commandments of the second Table, cryeth louder to God for vengeance, and unto Man for Justice than the shedding of innocent blood'. Society, in their view, could not ignore this insistent cry, and there was no way for it to "purify the land from the guilt of innocent blood, but by executing Justice upon the blood-shedder.' ${ }^{\prime 35}$ The author of the other tract steered clear of direct biblical references, but he was nonetheless convinced of Cook's guilt and was eager to associate her guilt with the stain of blood. In his view, the miscarriage which Cook suffered in Newgate prison was not enough to kill her because, as he put it: 'Providence had otherwise decreed, she must live to satisfy the justice of the Law, and be a terror to deter all others from being guilty of the like crime nay, if they have any Grace, from having any thoughts of so horrid a blood-guiltiness. ${ }^{\prime 36}$ The stress on deterrence, so apparent in this statement, correlates with a conviction that Cook's guilt was not only undeniable, but also particularly odious and worthy of punishment because she had shed the blood of an innocent.

Seventeenth-century historians are already familiar with the theme of blood-guilt because it constituted one of the principle charges brought against Charles I at his trial in 1648. Charles was condemned as a 'man of blood'. Ironically, the regicides would themselves be accused of the same crime when the tide turned against them in 1660-61. Blood-guilt was a fairly common theme, which appeared in seventeenth-century biblical commentary as well as discussions of power relations and violence. Religious enemies - in particular, the papists - were routinely accused of wallowing in innocent blood. The principle of blood-guilt hinged upon a distinction between 'innocent' and 'guilty' blood. Innocent blood represented a source of pollution, which, following biblical logic, could only be purged by restitution. The murderer's blood, in other words, was the only substance capable of atoning for the blood of the innocent. Since the 'cry' of unavenged innocent blood offended God, there was strong incentive to slay the guilty as the only means of making the necessary restitution. ${ }^{37}$

The imagery of blood was therefore a perfectly convenient shorthand for further sacralizing crime and punishment. Characters like the beleaguered Mary Cook might have provoked sympathy. But if the dichotomy between innocence and guilt were to hold, it was necessary to describe Cook's actions in such a way as to undercut this sympathy. The imagery of blood did exactly that. It drew attention to the innocence of the victim, exacerbated the guilt of the murderer, and concealed the workings of justice by conflating it with 'divine anger' and a presumed duty to rid the land of the filth of 
blood pollution. Other labels describing the illegitimacy of murder further reinforced the contrast between violence and justice. Cook's actions were 'barbarous', meaning here that they were unrestrained and undiscriminating. Her punishment, by contrast, was limited and proportional. Cook was 'inhumane', while her judge apparently qualified as clement because he at the very least invoked God's mercy for her soul.

Most of the terms which authors employed to couch their recriminations against Mary Cook and other criminals had long precedents, which included classical topoi and biblical rhetoric. This terminology had been part of the battery of execrations commonly found in medieval oral and literate culture, including clerical culture. ${ }^{38}$ By the sixteenth century, the countless authors whom we now group together under the unspecific heading of 'the press' had already transformed the language of blood-guilt, cruelty and inhumanity into mainstays of international and domestic propaganda. English-speaking pamphleteers, journalists and orators throughout the British Isles had become keen observers of how power was exercised in Europe and elsewhere. They frequently responded to international events through the use of diatribe of this type. But the process that made terms like 'cruel', 'bloody' and 'barbarous' commonplace was self-perpetuating, inasmuch as the reiteration of a common set of themes and expressions in ever-widening contexts of discussion gave them rapidly increasing currency. By the seventeenth century, many of these expressions had crystallized into stereotypes for describing illegitimate violence: the 'cruel tyrant', the 'inhumane savage', and the 'treacherous papist' bent on massacre.

In themselves, these formulas did not automatically have any bearing on the legitimization of judicial punishment. But several of them were likely to become relevant whenever retribution was at stake in the description of events. An excellent illustration of this is Sir Gerrard Lowther's inquisition in Ireland in the winter of 1652-53. As head of the High Court of Justice set up to try Sir Phelim O'Neill for the atrocities committed against Protestant settlers, Lowther presented himself as the human instrument in an 'inquisition for blood' ${ }^{39}$ Lowther did not limit his purview to the description of Irish atrocities, as was the case with most books and pamphlets. For obvious reasons, he was also concerned with the judicial context, the trial and punishment of an Irish 'rebel'. His words at the trial thus invite comparison with the demonization of Mary Cook 17 years later. In both cases, the use of formulas meant to vilify the criminal fit into an explicitly judicial context.

Lowther was convinced that an 'impartial inquisition for innocent blood' was essential in order 'to put away innocent blood from the land' ${ }^{40}$ In order to sustain the notion of a divine mandate, Lowther contrasted the 'wickedness' of the Irish rebels with the image of 'the innocent blood of Christians' which the Irish had 'wickedly and cruelly shed' against 'the Laws of God and man, of Nature and of nations, the Laws of the Land, and the rights and rules of war, and the bonds of Humanity and humane society' ${ }^{41}$ As in the 
case of Mary Cook, the themes of blood and blood-guilt were modulated by a series of other references alluding to a loss of self-restraint and to a descent into cruelty. Several witnesses had allegedly seen the rebels devise a 'variety of tortures and cruel deaths of the living' including exposure, starvation, burnings and similar acts. The 'savage cruelty', 'execrable malice' and 'hellish rage' of the Irish rebels had turned into outright 'devastation'. The rebels had targeted virtually everything connected with the protestant religion, the English nation and 'civility' itself; they had even murdered children and ripped unborn babies from their mothers' wombs. It seemed 'as though Infidels, or rather the wild beasts of the wilderness, wolves, and bears, and tigers, nay fiends and furies, had been brought into the Land'. ${ }^{42}$

For Lowther, the stereotype of the cruel Irishman, popularized by countless pamphlets, supported a caricatural distinction between brutal violence and the just rule of law, which he represented. The distinction was, in fact, a tricky one to sustain. Lowther had to explain why, under an infamous doublestandard dating back to a statute of Henry VII (10 Hen. VII, c. 21), Irish murderers had to be punished as though they were traitors, 'both with torture and with death'. Lowther could reason that Gaelic law had taught the native Irish that murder was a relatively minor offence, easily settled by the payment of blood fines. But the cruelty and barbarism of the Rebellion stood as better confirmation that, in Ireland, English customs were insufficient. Force, even though brutal, constituted a providential means of self-preservation. Thus, by invoking the ruthlessness of the Irish Lowther conveniently side-stepped any residual moral problems. ${ }^{43}$ Dramatizing the guilt of criminals was a good way of drawing the reader's attention away from the inherent violence of executions and corporal punishment, effectively robbing the condemned of his or her status as a potential victim.

The references to bloodshed and atrocity that filled the pages of murder pamphlets may have supplied convenient arguments for the killing of murderers, but what then of the men and women executed for lesser offences, including theft? To some extent, executions for theft were becoming less of an issue. In the late seventeenth century, sentences of transportation came to supplement the pardons, benefit of clergy, and the habit of convicting felons on lesser charges (punishable by whipping and branding) as an alternative to the death penalty. ${ }^{44}$ Many of the felons who ended their days on the gallows were either recidivists or guilty of aggravated crimes, such as highway robbery or house-breaking. But the guilt of these convicts still needed to be demonstrated, and protests about their cruelty and acts of bloodshed were both inappropriate and hard to justify given the context. Authors, therefore, found ways to compensate. Some chose to emphasize the sinful course of life that led to a progressive state of brutalization, and some pointed to the violence implicit in the work of the more notorious thieves. A cursory look at the literature reveals that these references to the audacity, 'notoriety' or callous indifference of particular convicts performed 
much the same function as allusions to blood and cruelty did in murder pamphlets. It has become fashionable to think that portraits of hardened criminals and their punishment enabled readers to infer moral lessons from the demise of these, their fellow-sinners. Many pamphleteers, however, seemed only marginally interested in stirring up deep feelings of empathy for these fallen brothers and sisters. Their sharp, caricatural distinctions between untainted innocence and exacerbated guilt prevented any easy identification between readers and even the most repentant convicts.

The accumulation of all of these accounts suggests that many of these writers were driven by a need to appease an underlying uncertainty about the legitimacy of punitive violence. The frequency of physical 'discipline' as a feature of early-modern English culture suggests that people were probably not particularly squeamish about the infliction of pain itself. One should not therefore assume that they were markedly troubled by the violence involved in punishment, in its own right. On the other hand they may have entertained reservations as to whether or not the guilty party really was guilty, or at least guilty enough to warrant the full severity of the law. How could they be sure that verdicts were reliable, or that punitive violence was legitimately punitive?

\section{V}

Punishment is a bit of a catch-all category. The punishment of self-confessed killers was one thing; that of mere thieves or, for that matter, of dissidents and marginals (a standard practice in Restoration Britain) was another. The formulas which authors and pamphleteers mobilized to castigate criminals and thereby whitewash the violence of punishment - were not, in fact, the exclusive property of any one ideological grouping. They were available for appropriation by propagandists speaking on the behalf of any one of a variety of groups that had reason to regard themselves as persecuted. One of the lines of thinking which these spokespeople often pursued involved maintaining the received categories and rhetorical formulas, but deploying them in such a way as to redirect blame. Under usual circumstances only the target of punishment would be identifiable as 'cruel' or otherwise depraved. But when the agents of punitive violence were found to be cruel - and the 'punished' innocent - the logic of punishment failed. ${ }^{45}$

By the second half of the seventeenth century, no group was more assiduous in turning the conventional language of justice and punishment against their persecutors than the Quakers. ${ }^{46}$ Friends actively compared the actions of the informers, local officials, clergymen and judges who persecuted them to those of European Catholics who martyred Protestants. From as early as 1660, motivated by a conviction that suffering constituted a powerful form of religious testimony, Friends had begun to collect reports from all over the British Isles and, indeed, from all over the world. By 1676, the 
sheer volume of their record-keeping necessitated the creation of a 'Meeting for Sufferings' which would compile and publicize reports of persecution. ${ }^{47}$ The resulting pamphlets and petitions were steeped in the rhetoric of cruelty and blood, and the fact that this rhetoric was often absent in the original reports demonstrates that it was being added for the purpose of dramatizing persecution. The overcrowding of men and women in tiny gaol cells translated into the worst form of tyranny, and even comparatively mild forms of pressure - the levying of fines, the distraint of poor people's goods, and the 'haling' of Friends gathered at religious meetings - were now framed in terms of 'barbarous cruelty'. ${ }^{48}$

Friends were not alone in portraying themselves as innocent martyrs pursued by depraved persecutors. From the inception of the Reformation, Protestants in the British Isles had refused to regard the prosecutions against their co-religionists at home, or in Catholic Europe, as legitimate 'punishments'. By the second half of the seventeenth century, the rhetoric of Protestant martyrology was being freely appropriated by almost all Nonconformists within the British Isles. ${ }^{49}$ Even Irish Catholics and uncompromising Scottish Conventiclers drew upon this cache of stereotypes and rationales to reprove their accusers. ${ }^{50}$ All of these groups sought, in effect, to de-sacralize the violence that other propagandists were trying very hard to sacralize. ${ }^{51}$

The best-known example of this kind of reverse smear campaign stems from the Whig martyrology created between 1688 and 1690, which chronicled the violence committed under James II. The figure dominating this martyrology was not James himself but rather his Lord Chief Justice and eventual Lord Chancellor, George Jeffreys. Jeffreys, as is well-known, had presided over the treason trials of 1685 following an uprising in south-western England in support of Charles II's illegitimate but Protestant son, the Duke of Monmouth. In 1685, following a now familiar pattern, Jeffreys had saddled his victims, the rebels, with the responsibility for severe reprisals that he himself was meting out. By 1689, however, Whig propagandists had redefined his proceedings as a mockery of justice and as an act of overt cruelty involving the brutalization of innocents. Their success was such that, to this day, the Jeffreys' trials are still remembered as 'the Bloody Assizes'. ${ }^{2}$

High politics, religious controversy and the propaganda it generated were obvious settings in which one might expect the validity of punishment to be questioned. But the tendency of even the unlikeliest of pressure groups to exploit the dichotomy between punitive justice and cruelty suggests that this dichotomy held sway in more banal contexts as well. The misgivings of the spectators who witnessed bungled executions may owe something to this habit of distinguishing between punishment and excessive violence. ${ }^{53}$ Clearer expressions of the popular desire to keep punishment distinct from cruelty routinely emanated from the press. The 'children's petition' against school whippings in the fall of 1669 is a case in point. The authors of this satirical pamphlet were not overly worried about the validity of corporal punishment itself, but 
they deplored the 'accustomed severities of school-discipline' on the grounds that England's schoolmasters so routinely brutalized their pupils that punishment had become as meaningless as it was pervasive. The schoolmaster's apparent sadism threatened to turn the rationale for punishment on its head, transforming the laudable goal of discipline into a cruel abuse of power. ${ }^{54}$

If this rhetoric meant anything, it would seem to be this: that England and the rest of the British Isles abounded in subjects bent as much on resisting as on applauding the rise of a potentially repressive legal system. Under Elizabeth, at a time when the English legal apparatus reached the height of its severity, commentators had turned to the press to debate the differences between punishment and violence, or punishment and cruelty. By the second half of the seventeenth century, at a time when new practices and new inclinations served to temper the severity of the law, justifications and condemnations of 'punishment' had both become regular topics of debate.

Both sides of this polemic, the justifications as well as the condemnations, must be regarded as twin facets of a common process. While many commentators sought to sacralize punishment, a number of their immediate contemporaries were doing the exact opposite: they questioned the legitimacy of punishment by pointing to its many abuses and drew as much attention as they could to the violence inflicted in the name of justice. In effect, the sacralization of punishment was a negotiated process that presupposed ideological conflict. People's willingness to buy, read or listen to stories about 'just' punishments was symptomatic of a context in which the arbitrary quality of punitive violence was under serious discussion. Far from accepting that violent punishments were normal or desirable, they needed to be reassured that punishment was not, in fact, violence - that it only targeted a minority of truly depraved individuals and, in so doing, helped to sustain a benevolent ordering of society.

By the seventeenth century, would-be defenders of public authority could exploit the increasingly mainstream machinery of the press to make their reassuring pieties heard. They were joined by a variety of hacks whose motivations were more mercantile. Money could be made by satisfying the demand for moral pieties, and publishers were on the lookout for materials that fit the bill. The pious competed with the chorus of dissenting voices who accepted the theoretical possibility of just punishment, but who bitterly resented the realities of seventeenth-century punitive practice. In this essay, I have put the purveyors of salacious stories and the odd balladeer on the same footing as a judge bent on condemning an Irish rebel, an engraver who thought it might be profitable to produce sensational plates depicting common forms of punishment, and a variety of sectarian pamphleteers. But this was a diverse cast of characters who occupied widely varying positions within the network of print culture.

Given the inherent diversity of these individuals' motivations, the fact that this propaganda should have been fairly consistent in its effects seems 
all the more revealing. Wherever we happen to look, we find the abstraction of punitive violence, the drawing of stereotypical dichotomies which opposed innocence to guilt and justice to cruelty, and the reinforcement of these categories through a stock of common formulas and examples. Reiteration was key, and the press itself was one of the most important driving forces in this respect. For all the attention historians have paid to juries and crowds, we should remember that only a minority of Englishmen and Englishwomen had any real contact with the criminal courts and their dealings. The majority simply glimpsed the punishment of offenders now and again. If they were to make sense of what punishment meant, they would have had to combine what they themselves knew about the subject with what the purveyors of opinion were telling them.

Between the consumers of opinion and the variety of producers and distributors, then, stood the press. It was the press, ultimately, and not religion or changes in the extent or effectiveness of prosecution, that lay at the heart of the cultural moment from which modern views of punishment emerged. The words of Chief Justice Gerard Lowther would not have mattered a minute after they had been uttered in the Winter of 1653, had it not been for the fact that they were printed up as part of Borlase's History of the Execrable Irish Rebellion in 1680. Without the press, the protests of the Quakers would likewise have passed into silence after victims complained and petitions were sent up to the relevant authorities. An expanding press was what drew these many voices into a public field of rhetoric, imbuing these arguments with some form of persistence. The press likewise fostered the rehashing of arguments by feeding people's uncertainty over the legitimacy of punitive violence and by fostering a need for frequent reassurance on this matter. Finally, the press was also the mechanism that transformed pre-existing rationales and formulas into what would become widely-used clichés.

When one reads about criminals on their way to Tyburn, greeted by acquaintances and strangers and plied with drink, one begins to wonder how far the opinions and rhetoric I have been exploring in this essay really extended. Britain would long be home to a set of cultures in which the ideological priorities of the literate classes proved a matter of popular indifference. The sacralization of punishment would therefore remain an unfinished process, extending only to a number of social strata. ${ }^{55}$ Yet it seems fairly clear that by the time the 'Bloody Code' was expanded, an entire class of 'respectable', literate individuals - the gens bien-pensants of the British Isles - had been saturated with the message that punishment belonged to an order of violence so completely distinct from commonplace aggression that it simply did not count as any kind of victimization. Individual members of this broad group had had opportunity to develop a set of ideological proclivities encouraging them to overlook the potential similarities between criminal and executioner. As early as 1650, anyone who wished to be so persuaded could have 
found ample assurances that the punished brought their 'just desserts' upon themselves. By the close of the seventeenth century such assurances had only become more plentiful. In such a context, the death penalty would not have seemed particularly violent, and the substitute punishments that did away with the immediate display of violence, such as transportation or imprisonment, could be hailed as the very epitome of 'civility' ${ }^{56}$

\section{Notes}

1 M. Foucault Discipline and Punish: The Birth of the Prison, trans. A. Sheridan (New York, 1979), chap. 2; R. McGowen, 'The body and punishment in eighteenthcentury England', Journal of Modern History, 59 (1978), 661-6; D. Hay, 'Property, authority and the criminal law', in D. Hay et al., eds, Albion's Fatal Tree: Crime and Society in Eighteenth-Century England (1975), 26-9. F. McLynn (Crime and Punishment in Eighteenth-Century England (London and New York, 1989), 258.

2 J.A. Sharpe, " "Last dying speeches": religion, ideology and public execution in seventeenth-century England', P\&P, 107 (1985), 144-167. See also P. Lake, 'Popular form, Puritan content? Two Puritan appropriations of the murder pamphlet from mid-seventeenth century London', in A. Fletcher and P. Roberts eds, Religion, Culture and Society in Early Modern Britain (Cambridge, 1994); and P. Lake, 'Deeds against nature: cheap print, protestantism and murder in early seventeenthcentury England', in K. Sharpe and P. Lake eds, Culture and Politics in Early Stuart England (Stanford, CA, 1993), 274-5; L. B. Faller, Turned to Account: The Forms and Functions of Criminal Biography in Late Seventeenth- and Early Eighteenth Century England (Cambridge 1987), chap. 5.

3 The expansion began immediately following the Glorious Revolution in 1688 and involved some 170 new capital offenses created between 1688 and 1818. For a brief overview, see H. Potter, Hanging in Judgement: Religion and the Death Penalty in England from the Bloody Code to Abolition (1993), 3-6.

4 My methodology involved calculating the sum of the titles containing particular keywords published within the specified range of years. STC codes were as follows: 'fi tiw execution and pyr 1550-1574'; 'fi tiw executed and pyr 1575-1599 not tiw execution'; and so on. I then controlled the resulting samples of titles so as to discard any titles that made use of any of the relevant words but did so in the wrong context (e.g. the 'execution' of orders). The resulting number of records is subsequently expressed as a percentage of the total number of titles published in that specific range of years.

5 Diarists sometimes recorded the circulation of the types of stories one associates with the penny-press. This was certainly the case with Thomas Rugge who left a number of entries on sensationalistic tales of crime and punishment. The Diurnal of Thomas Rugge, BL Add. MSS 10117, fos 94(v)-97; 100(v), 102-3, 150, 159(v). In describing executions, Narcissus Luttrell occasionally referred his reader to printed confessions. See A Brief Historical Relation of State Affairs from September 1678 to April 1714 (Oxford, 1857), I, 170 (10 March, 1681/2).

6 M. Gaskill, Crime and Mentalities in Early Modern England (Cambridge, 2000), 206-26; A. Walsham, Providence in Early Modern England (Oxford, New York, 1999), chap. 2.

7 W.P., 'A Sad and True Relation of the Apprehension, Tryal, Confession, Condemnation, and Execution of the Two Barbarous and Bloody Murtherers...', 
in H.E. Rollins ed., The Pepys Ballads (Cambridge, MA, 1930), 24-5. The same story was the subject of two separate pamphlets: The Bloody Murthers Executed; or, News From Fleet-Street (1675); and Bloud Justly Reveng'd (1675).

8 W.P., 'A Sad and True Relation', 24-5.

9 Anon., The Cruel Murtherer, Or the Treacherous Neighbour (1673), 7. On the same murder see anon., Bloody Nevvs from Shrewsbury (1673).

10 T. Reynolds, The Triumphs of Gods Revenge Against the Crying and Execrable Sinne of (Wilful and Premeditated) Murther (3rd edn, 1657). Other editions were printed in 1635, 1639, 1640, 1656, 1663, 1669, 1679, 1704, 1708, 1726, 1740, 1753, 1770 and 1778. On Reynolds' models see Walsham, Providence, 66-7.

11 Reynolds, Triumphs of Gods Revenge, 141-59.

12 Ibid., 153-7.

13 Ibid., 159.

14 Ibid., preface, fourth page. The reference is to Psalm 7.

15 T.M., Blood for Blood: Or Murthers Revenged (Oxford, 1661).

16 Ibid., dedication and 123.

17 For instance, E.S., The Witty Rogue Arraigned, Condemned, and Executed (1656). See also S. Smith, A True Account of the Behaviour, Confession, And Last Dying Speeches Of the Seven Criminals (1690).

18 R. Girard, Violence and the Sacred, trans. Patrick Gregory (Baltimore, 1977), chap. 1.

19 On the importance of contrition as a condition of mitigation, see C.B. Herrup, 'Law and morality in seventeenth-century England', P\&P, (1985), 118-9.

20 J. Seller, A Booke of the Punishments of the Common Laws of England (c. 1678).

21 R. McGowen, 'The changing face of God's justice: the debates over divine and human punishment in eighteenth-century England', CJH, 9 (1998), 63-98. For a close study of eighteenth-century assize sermons see also R. McGowen, "He beareth not the sword in vain": religion and the criminal law in eighteenthcentury England', Eighteenth Century Studies, 21 (1987-88), 192-211.

22 McGowen, 'He beareth not the sword in vain', 200-3.

23 See A. Babington, The English Bastille: A History of Newgate Gaol and Prison Conditions in Britain 1188-1902 (1971), 33-4. A. Marks, Tyburn Tree: Its History and Annals (1908), 63 and 213.

24 I am expanding here on S. Mullaney, The Place of the Stage: License, Play, and Power in Renaissance England (Chicago, 1988), 38-40. The fact that hangings were consigned to a geographical periphery did not detract from the public nature of these events. As Peter Linebaugh has noted, executions were well-advertised. P. Linebaugh, 'The Tyburn riot against the surgeons', in D. Hay et al., Albion's Fatal Tree.

25 See T. Laqueur, 'Crowds, carnival and the state in English executions, 1604-1868', in A.L. Beier et al., eds, The First Modern Society: Essays in English History in Honour of Lawrence Stone (Cambridge, 1989), 305-55. See also McLynn, Crime and Punishment, 274-5.

26 On the expectations weighing upon the hangman, see McLynn, Crime and Punishment, 269-70. On the variability of crowd responses, see J.A. Sharpe, 'Civility, civilizing processes, and the end of public punishment in England', in P. Burke et al., eds, Civil Histories: Essays Presented to Sir Keith Thomas (Oxford, New York, 2000), 220-2.

27 S. Amussen, 'Punishment, discipline, and power: the social meanings of violence in early modern England', JBS, 34 (1995), 5.

28 Ibid., 23.

29 This is especially true of J.A. Sharpe, Peter Lake and Lincoln Faller. 
30 Anon., The Cruel Mother (1670); and N. Partridge and B. Sharp, Blood for Blood Or Justice Executed for Inhumane Blood-Shed (1670). For discussion of the case itself, see M. Francus, 'Monstrous mothers, monstrous Societies: infanticide and the rule of law in Restoration and eighteenth-century England', Eighteenth-Century Life, 21(1997), 138-41.

31 The Cruel Mother, title and 6.

32 Partridge and Sharp, Blood for Blood, 1 and 15-16.

33 On the conventions and uses of this language in England and the British Isles see P. Rosenberg, 'The Moral Order of Violence: The Meanings of Cruelty in Early Modern England, 1648-1685' (PhD thesis Duke University, 1999). For an earlier parallel see C.A. Patrides, "The bloody and cruell Turke": the background of a Renaissance commonplace', Studies in the Renaissance, 10 (1963), 126-35.

34 The Cruel Mother, title, 3; Partridge and Sharp, Blood for Blood, title, 'To the Reader', $16-17$ and 19.

35 Partridge and Sharp, Blood for Blood, 1-2. This symbolism carried over into a discussion of the blood of Jesus and its powers of atonement. If Cook was genuinely repentant, Christ's blood would wash away her own blood guilt. See 'To the Reader' and 41-2.

36 The Cruel Mother, 6 (emphasis added).

37 P. Crawford, 'Charles Stuart, that man of blood', JBS, 16 (1977), 41-61; S. Baskerville, 'Blood guilt in the English Revolution', The Seventeenth Century, 8 (1993), 181-202; E. Tuttle, Religion et Idéologie dans la Révolution Anglaise, 1647-1649: Salut du Peuple et Pouvoir des Saint (Paris, 1989), chap. 9.

38 See B. Rosenwein, T. Head and S. Farmer, 'Monks and their enemies: a comparative approach', Speculum, 66 (1991), 771; H. Wieruszowski, 'Roger II of Sicily, rextyrannus in twelth-century political thought', Speculum, 38 (1963), 65-6.

39 The transcript of Lowther's speech appears under the title 'The Lord Lowther's speech, at the opening of High Court of Justice, at the trial of Phelim O Neal', in Edmund Borlase, The History of the Execrable Irish (1680), 305-14.

40 Lowther, in Borlase, History, 306.

41 Ibid., 306.

42 Ibid., 311.

43 Ibid., 311.

44 J.M. Beattie, Policing and Punishment in London, 1660-1750: Urban Crime and the Limits of Terror (Oxford, 2001), chap. 6.

45 Once again, this bears comparison with the arguments for abolishing the death penalty voiced during the Interregnum. See Zaller, 'The debate on capital punishment', 131-5.

46 This is a habit that Restoration Nonconformists shared with Elizabethan and Jacobean Catholics - the earlier specialists in this brand of rhetoric. For the catholic discourse on capital punishment see M. Questier and P. Lake, 'Agency, appropriation and rhetoric under the gallows: puritans, romanists and the state in early modern England', $P \& P, 153$ (1996), 64-107.

47 On the Meeting for Sufferings and its work see W. C. Brathwaite, The Second Period of Quakerism, 2nd edn, (Cambridge, 1961; reprinted, York, 1979), 282-5; and C. Horle, The Quakers and the English Legal System, 1660-1688 (1988), 161-5.

48 See, for instance, Anon., A Relation of the Inhumane and Barbarous Sufferings of the People Call'd Quakers (1665); [R. Allen], The Cry of Innocent Blood, Sounding to the Ear of Each Member in Parliament (London?, 1670); W. Penn, The Continued Cry of the Oppressed for Justice (1675); Anon., The Sad and Lamentable Cry of Oppression and Cruelty (1682). 
49 See N.H. Keeble, The Literary Culture of Nonconformity in Later Seventeenth-Century England (Athens, GA, 1987), chap. 2; and more crucially, J.R. Knott, Discourses of Martyrdom in English Literature, 1563-1694 (Cambridge, 1993), chaps 6-7.

50 Irish examples include R. S., A Collection Of Some of the Murthers and Massacres Committed on the Irish in Ireland (1662); P. Walsh, A Letter Desiring a Just and Mercifull Regard of the Roman Catholicks of Ireland (Dublin?, 1662); N. French, The Bleeding Iphigenia (1675). For the Scottish Conventiclers see J. Stewart, Naphtali, or the Wrestlings of the Church of Scotland (1667); (A. Shields?), A Hind Let Loose (Edinburgh?, 1687); A. Shields, A Short Memorial of the Suffering and Grievances ... of the Presbyterians in Scotland (Edinburgh, 1690).

51 Orthodox Protestants, it is worth noting, felt a distinct need to defend their honor against Nonconformist allegations of persecution. A particularly vivid example is N. Brisbie, Prosecution No Persecution (1682).

52 See the introductory remarks by J.G. Muddiman ed., The Bloody Assizes (Edinburgh and London, 1929), 6-8; and M. Zook, "'The Bloody Asizes": Whig martyrdom and memory after the Glorious Revolution', Albion, 27 (1995), 372-96. Variants include J. Tutchin, The Protestant Martyrs: or, The Bloody Assizes (1688?); J. Bent (J. Dunton), The Bloody Assizes (1689); [J. Tutchin], The Dying Speeches, Letters, and Prayers, \&c. of Those Eminent Protestants (1689); id., A New Martyrology, or, The Bloody Assizes (3rd edn, 1689).

53 See, for instance, Luttrell's comments on the executioner's failure to properly decapitate the traitor, Lord Russell, in July 1683 (A Brief Relation, 271). The incident itself was thought to warrant a printed explanation: J. Ketch, The Apologie of John Ketch, Esq., the Executioner of London (1683). For a German perspective see R. van Dülmen, Theatre of Horror: Crime and Punishment in Early Modern Germany, trans. E. Neu (Oxford, 1990), 113-18.

54 Anon., The Childrens Petition (1669), esp. 18-22, and 46-7.

55 For discussion of this point see, amongst others, Peter Linebaugh, The London Hanged: Crime and Civil Society in the eighteenth Century (Cambridge,1992), chaps 1 and 2.

56 On 'civilization' and the shifts in sentencing which began in the 'long' eighteenth century, see Sharpe's 'Civility, civilizing processes', and Judicial Punishment, 36-49. For trends in the nineteenth century see R. McGowen, 'Civilizing punishment: the end of the public execution in England', JBS, 33(1994), 257-82. 